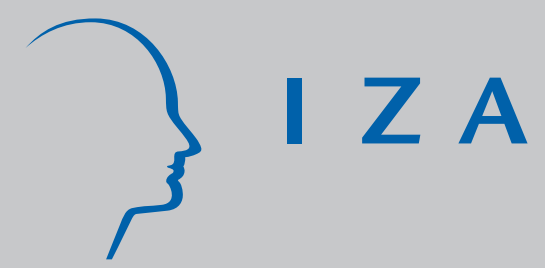

IZA DP No. 8050

Using Spatial Econometric Techniques to Analyze the Joint Employment Decisions of Spouses

Charlene M. Kalenkoski

Donald J. Lacombe

March 2014

Forschungsinstitut zur Zukunft der Arbeit Institute for the Study of Labor 


\title{
Using Spatial Econometric Techniques to Analyze the Joint Employment Decisions of Spouses
}

\author{
Charlene M. Kalenkoski \\ Texas Tech University \\ and IZA \\ Donald J. Lacombe \\ West Virginia University
}

\author{
Discussion Paper No. 8050 \\ March 2014
}

\author{
IZA \\ P.O. Box 7240 \\ 53072 Bonn \\ Germany \\ Phone: +49-228-3894-0 \\ Fax: +49-228-3894-180 \\ E-mail: iza@iza.org
}

Any opinions expressed here are those of the author(s) and not those of IZA. Research published in this series may include views on policy, but the institute itself takes no institutional policy positions. The IZA research network is committed to the IZA Guiding Principles of Research Integrity.

The Institute for the Study of Labor (IZA) in Bonn is a local and virtual international research center and a place of communication between science, politics and business. IZA is an independent nonprofit organization supported by Deutsche Post Foundation. The center is associated with the University of Bonn and offers a stimulating research environment through its international network, workshops and conferences, data service, project support, research visits and doctoral program. IZA engages in (i) original and internationally competitive research in all fields of labor economics, (ii) development of policy concepts, and (iii) dissemination of research results and concepts to the interested public.

IZA Discussion Papers often represent preliminary work and are circulated to encourage discussion. Citation of such a paper should account for its provisional character. A revised version may be available directly from the author. 


\section{ABSTRACT \\ Using Spatial Econometric Techniques to Analyze the Joint Employment Decisions of Spouses}

Studies of the joint time-use decisions of spouses have relied on joint estimation of time-use equations, sometimes assuming correlated errors across spouses' equations and sometimes directly examining the effects of one spouse's time use on another's, relying on panel data or instrumental variables techniques to account for endogeneity. However, panel data often are not available and available instruments often are not satisfactory, making examination of the direct relationship between spouses' time use difficult. Spatial econometric techniques applied to cross-sectional data do not require instrumental variables. This study estimates a Spatial Autoregressive (SAR) Model to examine the labor hours of husbands and wives in dual-earner couples using the 2012 Annual Social and Economic Supplement to the Current Population Survey (ASEC). In this model, each spouse is treated as a direct "neighbor" of the other in a spatial weight matrix and non-spouses are treated as non-neighbors. Estimates of both the own- and cross-wage effects on labor hours and an estimate of the direct relationship between spouses' labor hours are obtained.

JEL Classification: J22, D13

Keywords: employment, intrahousehold allocation of time, own- and cross-wage effects, spatial econometrics

Corresponding author:

Charlene M. Kalenkoski

Texas Tech University

Department of Personal Financial Planning

Human Sciences Room 242

1301 Akron Avenue

Box 41210

Lubbock, TX 79409-1210

USA

E-mail: charlene.kalenkoski@ttu.edu

\footnotetext{
* The authors thank Eakamon Oumtrakool for excellent research assistance.
} 


\section{Introduction}

There is a large labor supply literature that has concerned itself with the estimation of own- and cross-wage elasticities of labor supply (see Blau and Kahn, 2007; Song, 2007, and Cherchye et al., 2012 for recent examples). However, while cross-wage elasticities provide information about how the price of a spouse's time affects one's own labor supply, they do not provide direct information about how time in the labor market is related between spouses within a household. Some have attempted to model directly the time-use decisions of spouses by estimating spouses' time-use equations jointly, sometimes simply assuming correlated errors across these equations to account for the simultaneity of spouses' time-allocation decisions (Bloemen and Stancanelli, 2008; Bloemen et al., 2010), and sometimes directly regressing one spouse's use of time on another's, relying on a dynamic model and panel data (Lundberg, 1988) or on instrumental variables techniques (Hallberg and Klevmarken, 2003; Leeds and Von Allmen, 2004; Connelly and Kimmel, 2009), to account for endogeneity. Allowing correlated errors means allowing the unobserved variables affecting each spouse's time-use allocation to be correlated, but it does not allow measurement of the direct relationship between spouses' uses of time. Regressing one spouse's time use on another's does provide an estimate of the direct relationship, but panel data sometimes are difficult to come by and instruments often are not available or satisfactory.

One solution to the instrumental variables problem is to specify a cross-sectional spatial econometric model and estimate it via maximum likelihood. This study specifies a Spatial Autoregressive (SAR) Model and estimates it via maximum likelihood to examine the labor hours of husbands and wives in dual-earner couples using the 2012 Annual Social and Economic Supplement to the Current Population Survey (ASEC). This model treats each spouse as a direct "neighbor" of the other in a spatial weight matrix and non-spouses as non-neighbors. It is the specification of this weight matrix that allows estimation of the relationship between spouses' work hours without the need for 
instruments. Own- and cross-wage effects and an estimate of the direct relationship between husbands and wives' labor hours are obtained.

\section{Literature Review}

An early study that empirically examined the relationship between spouses' hours of work is Lundberg (1988). In her paper, she specifies a pair of simultaneous equations for each spouse's labor supply. She uses panel data and first differencing to control for heterogeneity and assortative mating. She also includes lagged hours to allow for habit formation. Looking at a sample of couples without children, she finds that husbands and wives act like separate individuals, that is, their labor hours are unrelated. However, she finds that couples with young children jointly determine their hours of work and that these work hours are positively related.

Hallberg and Klevmarken (2003) also use a simultaneous equations framework to examine parents' joint time-use decisions, but instead examine the direct relationship between parents' time with children and market work using cross-sectional data and Three Stage Least Squares (3SLS), an estimation method that requires instrumental variables. Their results suggest that a change in a mother's work hours has less influence on parents' time with children than a change in father's hours. Leeds and Von Allmen (2004) do not look at market work at all but do use a simultaneous equations framework to examine how spouses' household production time is related. In estimating their model, they predict each spouse's household production time and include that prediction in the other spouse's time-use equation. They find that working wives act as if their husbands are substitutes for home production while other wives are not. Like Lundberg (1988), they too find that the presence of children matters to the spousal time relationship. Husbands increase their time in home production when wives decrease their time, but only when children are present in the household. 
Connelly and Kimmel (2009) examine the effects of spouses' characteristics on time devoted to the leisure, child care, and housework of married mothers and fathers living with children under the age of 13. They consider five spousal variables, the relative wage of the wife compared to her husband, spouse's weekly hours of employment, and spouses' time in leisure, child care, and housework. They do not, unfortunately, consider the direct effect of one spouse's employment hours on the other spouse's employment hours. However, because they do examine the direct relationships between other uses of time, the spouse's time use variables require instrumentation in order to address issues of endogeneity and possible selection bias. Therefore, they use a predicted variable in place of the reported usual weekly hours of the spouse. They find that the relative wage does not appear to affect married parents' time-use choices. However, they find that mothers' home production time is reduced by increased employment hours of husbands and that caregiving time of either spouse is slightly increased when the other spouse's employment hours increase. Finally, spouses' time in leisure is found to be complementary.

Bloemen and Stancanelli (2008) estimate an empirical model that simultaneously specifies three time-use equations (paid work, child care, and housework) and a wage and employment equation for each spouse. The errors are assumed to be correlated across all equations. However, the authors do not examine the direct relationship between spouses' time use. They do find, however, that parents' market time responds positively to changes in one's own wage, while the own-wage elasticity of housework is negative and the own-wage elasticity of child care is zero. They also find that women's non-market time is independent of their husbands' wages. However, husbands respond to an increase in their wives' wage by increasing both housework and child care. Finally, they do find positive and significant correlations across the errors of the spousal equations, indicating that unobserved factors affect the time use of husbands and wives in the same direction. 
Bloemen et al. (2010) also examine simultaneously the time allocated by mothers and fathers to market work, child care, and housework. However, they do not estimate how the time spent by one spouse in any of these activities affects the time spent by the other in any of these activities. Instead, they allow the errors of the time-use equations to be correlated across spouses and find that unobserved factors affect the child care time of both parents in the same direction and that unobserved factors affect the housework time of both parents in opposite directions.

This study contributes to the literature by examining the direct relationship between spouses' labor hours using cross-sectional data and spatial econometrics techniques which do not require instruments. Using a sample of dual-earner couples from the 2012 ASEC, it is found that the labor hours of couples are spatially correlated with a highly statistically significant spatial autocorrelation parameter of 0.035 . This estimate indicates that as the weekly hours worked of one spouse increases by ten, the other spouse's weekly hours worked increases by 0.35 . Own- and cross-wage effects are estimated to be negative, with larger effects for women than for men.

\section{Model}

The SAR model to be estimated can be written as follows:

$$
H=\rho W H+X \beta+\varepsilon
$$

where $\mathrm{H}$ is an $\mathrm{nx} 1$ vector of hours worked, $\mathrm{X}$ is an $\mathrm{nxk}$ vector of explanatory variables that includes demographic characteristics, wage, and non-labor income, $\varepsilon$ is an $\mathrm{nx} 1$ error term, and $\rho$ and $\beta$ are the coefficients to be estimated. $W$ is a binary nxn spatial weight matrix which treats spouses in a household as "neighbors" and spouses living in different households as "non-neighbors." By convention, the spatial weight matrix $\mathrm{W}$ has zeros on the main diagonal because a person cannot be a neighbor to him/herself. It is standard practice to row-normalize the spatial weight matrix such that the rows of $\mathrm{W}$ sum to unity. When an $\mathrm{nx} 1$ vector $($ say, $\mathrm{H})$ is pre-multiplied by the spatial weight matrix $\mathrm{W}$, it 
produces a new vector $\left(\right.$ say $\left.\mathrm{H}^{*}\right)$ that is a weighted average of the surrounding values of the original matrix. In this case, the "average" refers to the $\mathrm{H}$ of only one neighbor, the spouse. ${ }^{1}$

Care must be taken when interpreting the coefficient estimates in the SAR model. As noted in LeSage and Pace (2009), the proper marginal effects that need to be interpreted are not the $\beta$ parameters. This can be seen by rewriting equation (1) in reduced form:

$$
H=\left(I_{n}-\rho W\right)^{-1}(X \beta)+\left(I_{n}-\rho W\right)^{-1} \varepsilon
$$

If we take the partial derivative of $\mathrm{H}$ with respect to $\mathrm{X}$, we obtain the following expression

$$
S(W)=\left(I_{n}-\rho W\right)^{-1}\left(I_{n} \beta\right)
$$

which is an nxn matrix of effects estimates that need to be interpreted. The diagonal elements of this matrix represent the direct effects, which tell us how a change in an explanatory variable for individual $\mathrm{i}$ affects the dependent variable for individual i. The off-diagonal elements of this matrix represent the indirect effects which indicate how a change in an explanatory variable for person i affects person j, where $i \neq j$. The total effects are the sum of the direct and indirect effects. In our example, the effects estimates will quantify how a change in an explanatory variable for one spouse affects his or her own hours directly (the direct effect) and how it will change his or her spouse's hours (the indirect effect). The total effect in this context is effect of the change in the explanatory variable on total labor hours in the household.

While direct, indirect, and total effects can be calculated for each household, LeSage and Pace (2009) have recommended that scalar summaries of the effects estimates in (3) be used. Therefore, we present the average direct effect, the average indirect effect, and the average total effect for each explanatory variable. We calculated but do not present confidence intervals for each of these quantities to determine their statistical significance as suggested by LeSage and Pace (2009).

\footnotetext{
${ }^{1}$ In an expanded model in which other household adults would be considered neighbors, this would be a weighted average of all household members' $\mathrm{H}$. In future work, we may consider additional household adults.
} 


\section{Maximum Likelihood Estimation of the Spatial Autoregressive Model}

The inclusion of the $W H$ term on the right hand side of the equation introduces simultaneity bias. As Franzese and Hays (2007, p. 45) note, “...the spatial lag, $W H$, being a weighted average of outcomes in other units, places the left-hand side of some observations on the right-hand side of others: textbook simultaneity." The simultaneity of the WH term on the right hand side renders OLS an inappropriate method to estimate the SAR model. In other words, OLS will not take into account the endogeneity of the $W H$ term (i.e. OLS is biased and inconsistent) and it proves necessary to find an alternative estimation strategy.

The two most common methods of overcoming the endogeneity of the $W H$ term are to use either a maximum likelihood or an instrumental variables technique. While it is often difficult to obtain valid instruments, most of the disadvantages associated with the maximum likelihood technique are computational in nature and have been overcome (LeSage and Pace, 2009).

Maximum likelihood estimation methods for spatial econometric models were first outlined by Ord (1975) and additional details are contained in Anselin (1988). In many cases, such as in the normal linear model, the successive observations in a sample are assumed to be statistically independent. In this case, the joint density of the entire sample is just the product of the densities of the individual observations. However in spatial samples, the observations are not statistically independent and the above method of building a likelihood function does not hold. One way in which to proceed is to use a multivariate density when the observations are not independent. The multivariate density can be written as follows (Kennedy, 2003, pp. 44):

$$
f(\varepsilon)=\left(2 \pi \sigma^{2}\right)^{-N / 2}|\Omega|^{-1 / 2} \exp \left\{\frac{1}{-2 \sigma^{2}} \varepsilon^{\prime} \Omega^{-1} \varepsilon\right\}
$$


As noted by Kennedy (2003, pp. 44), "A multivariate density function gives the density of an entire vector of $\varepsilon$ rather than just one element of that vector (i.e. it gives the 'probability' of obtaining the entire set of $\varepsilon_{i}$." A crucial idea behind this formulation of the likelihood function is that "this formula itself can serve as the likelihood function (i.e. there is no need to multiply a set of densities together since this formula has implicitly already done that, as well as taking account of interdependencies among the data) (Kennedy, 2003, pp. 45)."

\section{Data}

The data used in this analysis are from the 2012 ASEC supplement to the Current Population Survey (CPS). The CPS, administered monthly, is a labor force survey in which each household is interviewed multiple times. Information about demographic and other household-, family-, and personlevel characteristics is collected. The ASEC questions are added to the basic CPS questions during a three-month period, in February, March, and April, with most of the data collected in the month of March. Responses to the ASEC questions provide information about the labor hours worked and the labor and non-labor income received by each family member in the previous year (2011).

This paper focuses on the labor-hours decisions of dual-earner couples. Because the focus is on spouses and not other household members, in those households in which there is more than one dualearner couple but in which a primary couple (i.e., family) is identifiable, the spouses from the primary family are included but the spouses from other families in that household are not. Therefore, there is one husband observation and one wife observation from every household. There are 37,740 observations in our sample, exactly 18,870 husbands and 18,870 wives.

The dependent variable in the analysis is usual weekly hours worked in 2011. Explanatory variables include a dummy variable for female, a continuous age measure, a dummy variable for Hispanic, dummy variables for black, Asian, and other race (with white as the omitted category), dummy 
variables for highest education completed (with less than a high school degree as the omitted category), a dummy variable indicating whether there are children under age 6 in the household, a continuous measure of own non-labor income, and a continuous measure of own hourly wage. The measure of non-labor income used in the analysis is the sum of all alimony, child support, disability income, educational assistance, private financial assistance (i.e. from friends and family), public assistance (i.e. welfare), rental income, retirement income, social security, dividend income, supplemental security income, survivor's income, unemployment insurance, veteran's income, and worker's compensation received in 2011. The hourly wage measure is created by dividing total 2011 wage and salary earnings by the number of weeks worked in 2011 and by the number of hours usually worked per week.

\section{Results}

Table 1 shows descriptive statistics for the analysis sample. Table 2 provides maximum likelihood estimates of the average direct, average indirect, and average total effects from the SAR model. The key estimate is the spatial autocorrelation parameter, $\rho$, which is estimated to be 0.035 and is highly statistically significant. This effect indicates that if one spouse increased his/her hours of work by 10 , then the other spouse would increase his/her hours of work by 0.35 . This is a small, positive effect and is found for all households controlling for the presence of a child under age 6 in the household. Recall that previous evidence found a positive direct relationship only for households with children, so this is evidence that it matters even for spouses without children.

The direct wage effect is negative and statistically significant, indicating that, when the hourly wage goes up, hours of work decrease. This suggests that the income effect is greater than the substitution effect for dual-earner couples, on average. The indirect effect, interpreted as a cross-wage effect, is also estimated to be negative and statistically significant, but is smaller in magnitude. The interaction term between female and hourly wage also indicates negative and highly statistically 
significant direct and indirect effects, indicating that the own- and cross-wage negative effects are even larger in magnitude for females.

Both direct and indirect effects of non-labor income are negative and highly statistically significant, as theory would predict. The interaction term between female and non-labor income, however, indicates positive and highly statistically significant direct and indirect effects. Combining the negative non-labor income effects with their positive interaction effects indicates that overall direct and indirect effects of non-labor income are smaller for females than males.

The other variables have the expected effects. Being female directly reduces own weekly employment hours by 7.15 and this reduces her spouse's hours by 0.25 hours, for a total reduction in household employment of 7.4 hours. Age, being Hispanic, and having children under age 6 in the household all have negative effects on one's own hours of work but also smaller effects on one's spouse's hours of work. Being black and having at least a college degree, on the other hand, have positive effects on one's own hours of work and positive smaller effects on one's spouse's hours of work.

\section{Conclusion}

There is a large labor supply literature that has concerned itself with the estimation of own- and cross-wage elasticities of labor supply. However, while cross-wage elasticities provide information about how the price of one spouse's time affects the other's labor supply, they do not provide information about how time in the labor market is directly related between spouses within a household. Studies that have attempted to model directly the joint time-use decisions of spouses have relied on joint estimation of time-use equations, sometimes assuming correlated errors among spouses' reducedform time-use equations, and sometimes directly examining the relationships between the spouses' uses of time, relying on panel data or instrumental variables techniques to account for endogeneity. 
However, panel data often are not available and available instruments often are not satisfactory. Spatial econometrics techniques do not require instrumental variables. This study uses a SAR model to examine the relationship between the hours worked of husbands and wives in dual-earner couples using the 2012 ASEC. In this model, each spouse is treated as a direct "neighbor" of the other in a spatial weight matrix and non-spouses are treated as non-neighbors. We obtain a direct estimate of the relationship between spouses' hours of work that is positive and indicates that an increase in one spouse's hours of work by 10 increases the other spouse's hours of work by 0.35 . We also obtain negative own- and crosswage effects. Future work will extend the analysis to include couples in which at least one spouse does not work, to include other household adults, and to home production and leisure activities. 
Table 1: Descriptive Statistics

\begin{tabular}{|c|c|c|}
\hline Variable Name & Mean & $\begin{array}{c}\text { Standard } \\
\text { Deviation }\end{array}$ \\
\hline Female & .50 & .50 \\
\hline Age & 44.31 & 11.00 \\
\hline Hispanic & 0.13 & 0.33 \\
\hline Black & 0.07 & 0.26 \\
\hline Asian & 0.06 & 0.24 \\
\hline Other Race & 0.03 & 0.16 \\
\hline $\begin{array}{c}\text { Graduate or Professional } \\
\text { Degree }\end{array}$ & 0.16 & 0.37 \\
\hline College Degree & 0.266 & 0.44 \\
\hline High School Degree & 0.24 & 0.43 \\
\hline Children <6 Years & 0.25 & 0.44 \\
\hline Non-Labor Income & $3,200.43$ & $10,570.46$ \\
\hline Hourly Wage & 26.87 & 39.51 \\
\hline
\end{tabular}


Table 2: Average Direct, Average Indirect, and Average Total Effects

\begin{tabular}{|c|c|c|c|}
\hline Variable Name & $\begin{array}{c}\text { Average Direct } \\
\text { Effect }\end{array}$ & $\begin{array}{c}\text { Average Indirect } \\
\text { Effect }\end{array}$ & $\begin{array}{c}\text { Average Total } \\
\text { Effect }\end{array}$ \\
\hline Female & $\begin{array}{c}-7.150094^{* * *} \\
(-52.2586)\end{array}$ & $\begin{array}{c}-0.249996 * * * \\
(-52.3657)\end{array}$ & $\begin{array}{c}-7.400090 * * * \\
(-52.2705)\end{array}$ \\
\hline Age & $\begin{array}{c}-0.042096 * * * \\
(-6.990)\end{array}$ & $\begin{array}{c}-0.001472^{* * *} \\
(-6.9913)\end{array}$ & $\begin{array}{c}-0.043568 * * * \\
(-6.9901)\end{array}$ \\
\hline Hispanic & $\begin{array}{c}-0.785436 * * * \\
(-4.9138) \\
\end{array}$ & $\begin{array}{c}-0.027462 * * * \\
(-4.9129) \\
\end{array}$ & $\begin{array}{c}-0.812899 * * * \\
(-4.9138) \\
\end{array}$ \\
\hline Black & $\begin{array}{c}0.501397^{* *} \\
(2.4477) \\
\end{array}$ & $\begin{array}{c}0.017531^{* *} \\
(2.4475)\end{array}$ & $\begin{array}{c}0.518928^{* *} \\
(2.4477)\end{array}$ \\
\hline Asian & $\begin{array}{c}-0.680778 * * * \\
(-3.0158)\end{array}$ & $\begin{array}{c}-0.023803 * * * \\
(-3.0157)\end{array}$ & $\begin{array}{c}-0.704580^{* * *} \\
(-3.0160)\end{array}$ \\
\hline Other Race & $\begin{array}{c}0.009810 \\
(0.0282) \\
\end{array}$ & $\begin{array}{c}0.000343 \\
(0.0283) \\
\end{array}$ & $\begin{array}{c}0.010153 \\
(0.0283) \\
\end{array}$ \\
\hline $\begin{array}{l}\text { Graduate or Professional } \\
\text { Degree }\end{array}$ & $\begin{array}{c}3.330652 * * * \\
(19.4411)\end{array}$ & $\begin{array}{c}0.116454 * * * \\
(19.4095)\end{array}$ & $\begin{array}{c}3.447106 * * * \\
(19.4405)\end{array}$ \\
\hline College Degree & $\begin{array}{c}1.607941 * * * \\
(11.3923)\end{array}$ & $\begin{array}{c}0.056220 * * * \\
(11.3926)\end{array}$ & $\begin{array}{c}1.664161^{* * *} \\
(11.3924)\end{array}$ \\
\hline High School Degree & $\begin{array}{c}-0.016084 \\
(-0.1162) \\
\end{array}$ & $\begin{array}{c}-0.000562 \\
(-0.1161) \\
\end{array}$ & $\begin{array}{c}-0.016646 \\
(-0.1162) \\
\end{array}$ \\
\hline Children $<6$ Years & $\begin{array}{c}-1.366888 * * * \\
(-9.0360)\end{array}$ & $\begin{array}{c}-0.047792^{* * *} \\
(-9.0320)\end{array}$ & $\begin{array}{c}-1.414680 * * * \\
(-9.0359)\end{array}$ \\
\hline Non-labor Income & $\begin{array}{c}-0.000096 * * * \\
(-15.0929)\end{array}$ & $\begin{array}{c}-0.000003^{* * *} \\
(-15.1192)\end{array}$ & $\begin{array}{c}-0.000099 * * * \\
(-15.0940)\end{array}$ \\
\hline Hourly Wage & $\begin{array}{c}-0.012305^{* * *} \\
(-7.7370)\end{array}$ & $\begin{array}{c}-0.000430 * * * \\
(-7.7374)\end{array}$ & $\begin{array}{c}-0.012735^{* * *} \\
(-7.7370)\end{array}$ \\
\hline Non-labor Income*Female & $\begin{array}{c}0.000032 * * * \\
(2.9386)\end{array}$ & $\begin{array}{c}0.000001 * * * \\
(2.9390)\end{array}$ & $\begin{array}{c}0.000033 * * * \\
(2.9386)\end{array}$ \\
\hline Hourly Wage*Female & $\begin{array}{c}-0.005301^{*} \\
(-1.6640) \\
\end{array}$ & $\begin{array}{c}-0.000185^{*} \\
(-1.6640) \\
\end{array}$ & $\begin{array}{c}-0.005486^{*} \\
(-1.6640) \\
\end{array}$ \\
\hline Spatial Autocorrelation: $\rho$ & $\begin{array}{l}0.0350 * * * \\
(529.9078)\end{array}$ & & \\
\hline
\end{tabular}

t-statistics are in parentheses. ${ }^{*}$ represents statistically significant at the $10 \%$ level. ${ }^{* *}$ represents statistically significant at the $5 \%$ level. ${ }^{* * *}$ represents statistically significant at the $1 \%$ level. 


\section{References}

Anselin, Luc (1988). Spatial Econometrics: Methods and Models Vol. 4. : Dordrecht: Springer.

Baltagi, Badi (Ed.). (2008). A Companion to Theoretical Econometrics. Oxford: Backwell Publishing

Blau and Kahn (2007). “Changes in the Labor Supply Behavior of Married Women: 1980-2000," Journal of Labor Economics 25(3): 393-438.

Bloemen, Hans G. and Elena G. F. Stancanelli (2008). “How Do Parents Allocate Time? The Effects of Wages and Income," IZA Discussion Paper No. 3679.

Bloemen, Hans G., Silvia Pasqua, and Elena G. Stancanelli (201). “An Empirical Analysis of the Time Allocation of Italian Couples: Are They Responsive?" Review of Economics of the Household 8: 345-369.

Cherchye, Laurens, Bram De Rock, and Frederic Vermeulen (2012). “Married with Children: A Collective Labor Supply Model with Detailed Time Use and Intrahousehold Expenditure Information," American Economic Review 102(7): 3377-3405.

Connelly, Rachel and Jean Kimmel (2009). "Spousal Influences on Parents' Non-Market Time Choices," Review of Economics of the Household 7: 361-394.

Franzese, Robert . J., \& Hays, Jude . C. (2007). "Spatial Econometric Models of Cross-Sectional Interdependence in Political Science Panel and Time-series-cross-section Data," 15(2): 140-164. Hallberg, Daniel and Klevmarken, Anders (2003). "Time for Children: A Study of Parent's Time Allocation," Journal of Population Economics 16: 205-226.

Kennedy, Peter. (2003). A Guide to Econometrics. Cambridge: MIT press.

Leeds, Michael A. and Peter Von Allmen. "Spousal Complementarity in Home Production," The American Journal of Economics and Sociology 63(4): 795-811.

LeSage, James P. and R. Kelley Pace (2009). Introduction to Spatial Econometrics. CRC Press: Boca Raton. 
Lundberg, Shelly (1988). "Labor Supply of Husbands and Wives: A Simultaneous Equations Approach," Review of Economics and Statistics 70(2): 224-35.

Ord, Keith (1975). "Estimation Methods for Models of Spatial Interaction," Journal of the American Statistical Association 70(349): 120-126.

Song, Younghwan (2007). "The Working Spouse Penalty/Premium and Married Women's Labor Supply," Review of Economics of the Household 5: 279-304. 